\title{
OBSTRUCTION OF DRIPPERS AS A RESULT OF APPLICATION OF MOISTURIZED WHITEWASH IN IRRIGATION WATER
}

\section{CÍCERO R. A. BARBOZA JÚNIOR ${ }^{1}$, JOÃO A. LELIS NETO ${ }^{2}$, MARCELO P. HARTWIG ${ }^{3}$, ALLAN C. BARROS ${ }^{4}$, RUBENS D. COELHO ${ }^{5}$}

\begin{abstract}
Plug dynamics of non compensate drip tubes were evaluated, by the precipitation of moisturized whitewash $\left[\mathrm{Ca}(\mathrm{OH})_{2}\right]$, which is used in the fertigation for the bulb $\mathrm{pH}$ control of the trademarks Azud, Amanco, Naandan, Netafim, Petroisa, Queen Gil, with flow rate varying between 0.4 to $3.0 \mathrm{~L} \mathrm{~h}^{-1}$ usually used in the country. For this matter, increasing doses of $\mathrm{Ca}(\mathrm{OH})^{2}$ were applied in the irrigation water, from $0.01 \mathrm{~g} \mathrm{~L}^{-1}$ to $1.84 \mathrm{~g} \mathrm{~L}^{-1}$. The flow rate of each drip tube was measured in intervals of time initially of 7 days, later of 15 days of system operation, totaling a time of 100 days of operation, corresponding to nine applications or 432 hours. The coefficient of variation $(\mathrm{CV})$, and relative rate flow $(\mathrm{Qr})$ were evaluated. The results pointed differences among the evaluated emitter regarding the occurrence of the clogging, and the models G2 and G5 presented the smallest levels of flow rate variation comparing to the models G6, G7 and G9.
\end{abstract}

KEYWORDS: drip tube, clogging evaluation, hydrated lime.

\section{OBSTRUÇÃO DE GOTEJADORES RESULTANTE DA APLICAÇÃO DE CAL HIDRATADA NA ÁGUA DE IRRIGAÇÃO}

RESUMO: Foi avaliada a dinâmica de entupimento de nove tubogotejadores não compensantes, por precipitação de cal hidratada $\left[\mathrm{Ca}(\mathrm{OH})_{2}\right]$, utilizada na fertirrigação para controle de $\mathrm{pH}$ do bulbo, nas marcas comerciais Azud, Amanco, Naandan, Netafim, Petroisa e Queen Gil, com vazões variando entre 0,4 e 3,0 $\mathrm{L} \mathrm{h}^{-1}$, comumente utilizadas no País. Para tanto, foram aplicadas doses crescentes de $\mathrm{Ca}(\mathrm{OH})_{2}$ na água de irrigação, entre $0,01 \mathrm{~g} \mathrm{~L}^{-1}$ e $1,84 \mathrm{~g} \mathrm{~L}^{-1}$. A vazão de cada gotejador foi medida em intervalos de tempo inicialmente de 7 dias, posteriormente de 15 dias de funcionamento do sistema, totalizando um tempo de 100 dias de operação, correspondentes a nove aplicações ou 432 horas. Foram avaliados o coeficiente de variação (CV) e a vazão relativa (Qr). Os resultados apontaram diferenças entre os emissores avaliados quanto à ocorrência do entupimento, tendo os modelos G2 e G5 apresentado os menores níveis de variação de vazão em relação aos modelos G6, G7 e G9.

PALAVRAS-CHAVE: tubo gotejadores, evolução de entupimento, hidróxido de cálcio.

\section{INTRODUCTION}

With the imminent charges for water use, and with the scarcity of this resource, we ought to opt for more efficient irrigation systems, applying water only to the necessary quantity, aiming to increase the efficiency of using this input. In this context, localized irrigation systems, including the drip, can provide greater efficiency, usually above 90\%, applying small flow rates with low pressure due to more efficient control of irrigation depth (BERNARDO et al., 2006; RESENDE, 1999). BERNARDO et al. (2006) adds that the efficiency and uniformity of water application of this method result in benefits for crops, increasing production, improving quality and reducing costs by saving water, fertilizer and manpower.

\footnotetext{
${ }^{1}$ Doutorando em Ciências (Irrigação e Drenagem), Departamento de Engenharia de Biossistemas, ESALQ/USP, Piracicaba - SP, Fone: (0XX19) 3447.8554, cicerorenejr@yahoo.com.br.

${ }^{2}$ Doutorando em Ciências (Irrigação e Drenagem), Departamento de Engenharia de Biossistemas, ESALQ/USP.

${ }^{3}$ Prof. Dr., Curso Tecnológico em Saneamento Ambiental, IFsul, Pelotas - RS.

${ }^{4}$ Prof. Dr., Curso de Agronomia, UFAL, Câmpus Arapiraca, Arapiraca - AL.

${ }^{5}$ Prof. Associado, Departamento de Engenharia de Biossistemas, ESALQ/USP, Piracicaba - SP.

Recebido pelo Conselho Editorial em: 9-3-2010
}

Aprovado pelo Conselho Editorial em: 20-6-2011 
In localized irrigation, water quality can compromise the uniformity of application. The clogging, which is caused mainly by the passage of water through small holes, according to PIZARRO (1996), appears as the greatest technological challenge of the method. The precipitation of calcium carbonate is the most common type of chemical obstruction in the drip irrigation (DIAS et al., 2004). The application of acids decreases the obstructions caused by chemical precipitates, reducing the $\mathrm{pH}$ of the water and increasing the solubility of these elements, keeping them in solution; this practice has been recommended by several authors (TEIXEIRA, 2006; MEYER, 1985). However, this technique increases the acidity of the wet bulb on the soil.

To correct the soil acidity, one option is the application of the hydrated lime $\mathrm{Ca}(\mathrm{OH})_{2}$ via irrigation water. Hydrated lime appears as a white powder, alkaline ( $\mathrm{pH} 12.8)$ and slightly soluble in water (solubility of $1.2 \mathrm{~g} /$ liter of water at a temperature of $25^{\circ} \mathrm{C}$ ). His power of neutralization (PN) is 1.35 ; that means that $100 \mathrm{~kg}$ of $\mathrm{Ca}(\mathrm{OH})_{2}$ are equivalent to $135 \mathrm{~kg}$ of $\mathrm{CaCO}_{3}$. Brazilian law requires minimum values for the PN correction: $67 \%$ for lime and other (marl, middens); $125 \%$ for pure agricultural lime; $94 \%$ for hydrated agricultural lime; $60 \%$ for dross; and $80 \%$ for agricultural calcined limestone (ALCARDE, 1992). Hydrated lime is a strong base which is obtained from the calcination of calcium carbonate $\left(\mathrm{CaCO}_{3}\right)$, until its transformation into calcium oxide $(\mathrm{CaO}$ quicklime). And through the hydration of calcium oxide in industrial processes, the calcium hydroxide $\mathrm{Ca}(\mathrm{OH})_{2}$ is formed. Its components are magnesium hydroxide $\mathrm{Mg}(\mathrm{OH})_{2}$, calcium hydroxide $\mathrm{Ca}(\mathrm{OH})_{2}$.

However, there is no research reporting the effect of clogging that the hydrated lime might cause in the irrigation system when applied through irrigation water. In this context, the objective was to study the potential for water blockage containing hydrated lime at concentrations ranging from $0.01 \mathrm{~g} \mathrm{~L}^{-1}$ to $1.84 \mathrm{~g} \mathrm{~L}^{-1}$ in nine types of non-compensating drip tubes, and the later attempt of clearing with the application of nitric acid $\left(\mathrm{HNO}_{3}\right)$.

\section{MATERIAL AND METHODS}

The experiment was conducted at the Hydraulics Laboratory of the Department of Irrigation and Drainage, of the College of Agriculture "Luiz de Queiroz" - ESALQ/USP, located in Piracicaba, São Paulo State. The experiment was conducted in a test bench built in metal structure, composed of three floors, with $11.0 \mathrm{~m}$ long, $4.0 \mathrm{~m}$ wide, and $5.80 \mathrm{~m}$ high, each floor of the bench independent of the other, allowing simultaneous research testing. This experiment was conducted in the first block of the second sector (Figure 1a), composed of nine lines, with ten drip tubes marked per line, totaling 90 evaluated drip tubes. In Figure $1 \mathrm{~b}$ the container used in the test can be seen.
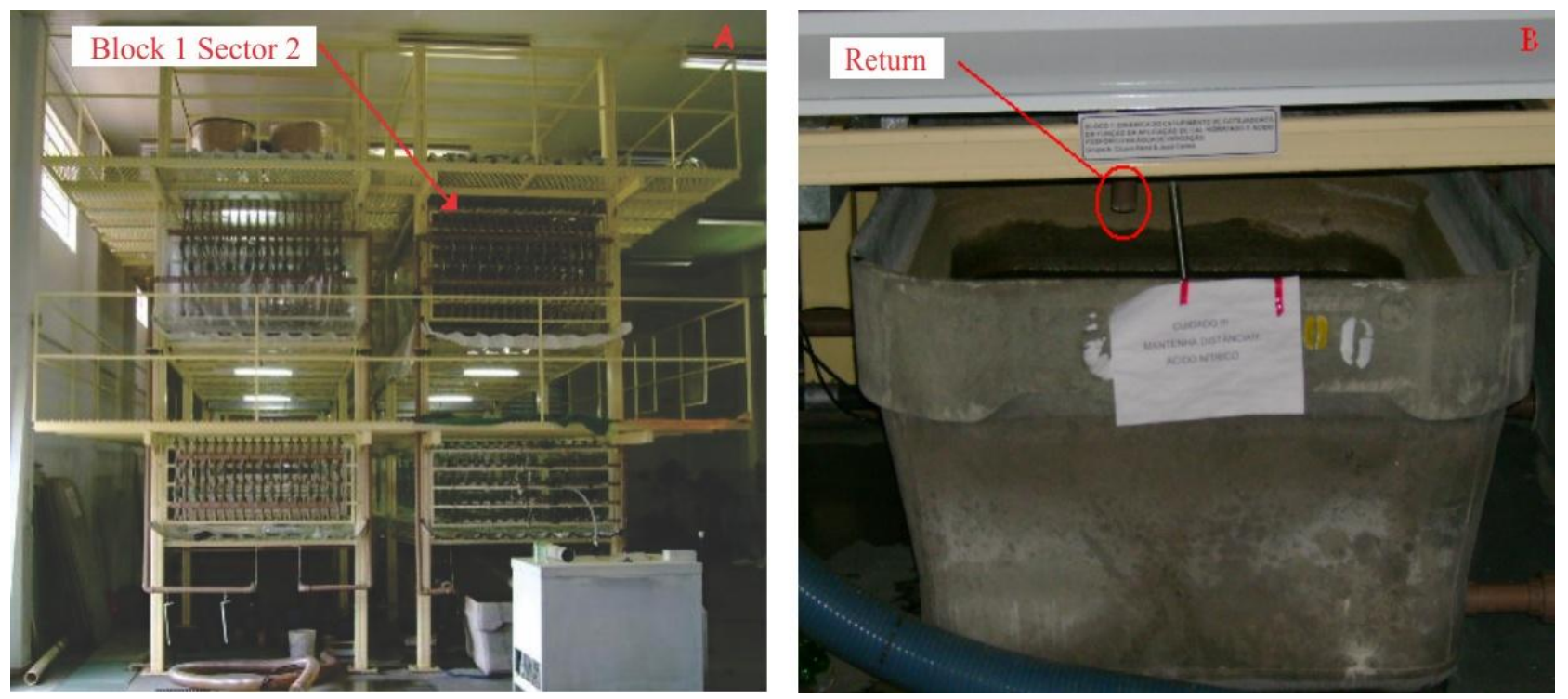

FIGURE 1. a) Detail of the sector where the experiment was run; b) Preparation tank of the solution $\left[\mathrm{Ca}(\mathrm{OH})_{2}\right]$. 
The statistical delineation used was the factorial, with nine models and nine applications (factor $9 \times$ 9), and each emitter considered as a experimental plot, and each plot repeated ten times, in other words, 10 (ten) emitters were evaluated in each line. We chose to test the drip tubes using the commercial space (distance between drip-DEG, Table 1) and not to separate the drip tubes to the test bench, thus avoiding differences related to the influence of amendments and the proximity of the emitters, thus adopting conditions similar to field conditions. RESENDE (1999) and TEIXEIRA (2006), suggest the same, because the original maintenance of the plant spacing helps to reduce errors and better represent the actual condition of irrigation systems.

We used the statistical "software" SAS (STATISTICAL ANALYSIS SYSTEM, 2003), with significance levels of $5 \%$ for the $\mathrm{F}$ test, and the means compared by Tukey test at $5 \%$ significance level.

The flow rates of the drippers were determined by gravimetric method, the flow rate was collected during the period of $5 \mathrm{~min}$, and the weight of the water collected was measured using an electronic scale (precision 0.01g). The measurements were taken at weekly intervals (up to sixth reading), and from that, at fortnightly intervals. When making the measurement, each emitter was carefully observed, which means to not have interference from adjacent drippers and/or connection points; in order to do that, strings were used to isolate the flow of each dripper. As the drip lines have different distances between the drippers (DEG, Table 1), so there would be the same amount of evaluated emitters, 10 emitters were selected in each line, thus consisting of repetitions. These were marked and maintained throughout the experiment.

Evaluations of relative flow rates were made (Qr, eq. 1), the flow coefficient of variation (CV, eq.2) that, according to Solomon (1979), is an important parameter that influences the uniformity of the water emission and the efficiency of water application through the system.

$$
\mathrm{Qr}=\frac{\mathrm{q}_{\text {novo }}}{\mathrm{q}_{\text {atual }}}
$$

where,

$\mathrm{q}_{\text {novo }}=\frac{\mathrm{m}}{1000 \mathrm{t}} 60$

qatual - flow rate collected, $\mathrm{L} \mathrm{h}^{-1}$;

$\mathrm{m}$ - mass of water collected, $\mathrm{g}$, and

$\mathrm{t}$ - collection time, min.

$$
\mathrm{CV}=\frac{\mathrm{s}}{\mathrm{q}_{\mathrm{med}}} 100
$$

where,

$\mathrm{CV}$ - flow coefficient of variation, \%;

$\mathrm{s}$ - standard deviation of emitter flow, $\mathrm{L} \mathrm{h}^{-1}$, and

$\mathrm{q}$ med - media flow from emitters, $\mathrm{L} \mathrm{h}^{-1}$

We evaluated nine models drip tubes, from the trademarks Azud, Carborundum, Naandan, Queen Gil, Petroisa, Plastro and Netafim (from the last two trademarks, two models of each were evaluated), commonly used in systems deployed in Brazil. The emitters used are from the types of drip tape, bob, flat, tortuous-path, turbulent-flow, and presented, in preliminary tests, coefficient of uniformity variation - CV between 1.24 and 4.90\% (Table 1) considered good (CV <10\%) according to HILLEL (1982); the technical data of each type of emitter used are in Table 1. In the discharge piping, a filter screen of 120 mesh or $130 \mu \mathrm{m}$ (Amiad) was used. 
TABELA 1. Description of the drippers: model, rate flow, diameter $(\varnothing \mathrm{N})$, coefficient of variation $(\mathrm{CV})$ and distance between emitters (DBE).

\begin{tabular}{cccccc}
\hline Model & Type & *Flow L.h & Initial CV & $\varnothing \mathrm{N}(\mathrm{mm})$ & DEG $(\mathrm{m})$ \\
\hline G1 & Flat & 2.0 & 1.64 & 16.0 & 0.75 \\
G2 & Bob & 3.0 & 3.47 & 17.0 & 0.40 \\
G3 & Flat & 2.0 & 3.81 & 16.0 & 0.80 \\
G4 & Flat & 2.1 & 4.20 & 17.0 & 0.75 \\
G5 & Flat & 2.0 & 2.11 & 16.0 & 0.60 \\
G6 & Flat & 1.4 & 1.24 & 17.0 & 0.50 \\
G7 & Flat & 1.5 & 4.90 & 16.0 & 0.30 \\
G8 & Bob & 2.2 & 4.37 & 16.0 & 0.50 \\
G9 & Tape & 0.4 & 4.22 & 16.5 & 0.10 \\
\hline
\end{tabular}

*Flow to operating pressure of $150 \mathrm{kPa}$.

Because there is no technical standard for this type of test, $\mathrm{Ca}(\mathrm{OH})_{2}$ with $85 \%$ purity was added to the water. The treatment consisted of application of five increasing concentrations over time, in order to make the response of the test faster. The concentrations were $0.01,0.02,0.92,1.41$ and $1.84 \mathrm{~g} \mathrm{~L}^{-1}$, corresponding to $0.7,1.4,65.0,100.0$ and $130.0 \%$ of complete solubility of pure lime which is $1.2 \mathrm{~g} \mathrm{~L}^{-1}$ at $25^{\circ} \mathrm{C}$. The increasing concentrations were applied as follows: $0.01 \mathrm{~g} \mathrm{~L}^{-1}$ from $0 \mathrm{~h}$ to $72 \mathrm{~h} ; 0.02 \mathrm{~g} \mathrm{~L}^{-1}$ from $72 \mathrm{~h}$ to $108 \mathrm{~h} ; 0.92 \mathrm{~g} \mathrm{~L}^{-1}$ from $108 \mathrm{~h}$ to $144 \mathrm{~h} ; 1.41 \mathrm{~g} \mathrm{~L}^{-1}$ from $144 \mathrm{~h}$ to $216 \mathrm{~h} ; 1.84 \mathrm{~g} \mathrm{~L}^{-1}$ from $216 \mathrm{~h}$ to $432 \mathrm{~h}$.

The water temperature in the laboratory ranged from 18 to $26^{\circ} \mathrm{C}$ during the experiment. The solution was prepared directly in the water tank used for enforcement.

The system was turned on and applied the solution for a period of 12 uninterrupted hours, after this period was then turned off, staying at standby for 36 hours. This procedure was repeated for the duration of the experiment. The system applied the solutions continuously with constant service pressure of $150 \mathrm{kPa}$. The water used during the experiment was water from treated center and packed in an asbestos box of thousand liters. The solution of $\mathrm{Ca}(\mathrm{OH})_{2}$ remained under constant agitation during the irrigation. At the end of three irrigations, the solution was replaced by another. For this experiment, the system worked for a period of 432 hours.

At the end of $432 \mathrm{~h}$ of application of $\mathrm{Ca}(\mathrm{OH})_{2}$, four applications were made of nitric acid $\left(\mathrm{HNO}_{3}\right)$ solution at $\mathrm{pH}$ 2.0. The system was washed with water, then the solution of nitric acid was applied for a period of 5 minutes at a constant pressure of $150 \mathrm{kPa}$, and next, with the final line of drip tubes closed, a repose of one hour was made with acid within the hoses. At the end of one hour, the system was put into operation for 23 hours with clean water, after which a new application of acid was made with the same procedure. After completing the four applications of acid, a new flow reading was made to gain the results.

\section{RESULTS AND DISCUSSIONS}

As the tested emitters are commercial products, data and analysis here presented were coded to avoid commercial speculation of the results, since the tests conducted are not standardized. The numbers used in the encoding of the emitters models (G1, G2, G3, .., G9), have nothing to do with the product brand names, nor with the sequence of emitters shown in Table 1.

Figure 2 shows the graphs for each dripper, containing values of initial relative flow (Qr) and during the applications for the nine drip tubes and the coefficient of variation of production (before time zero in the graphs) and coefficient of flow variation (CV) throughout the experiment. It may be noted on the graphs that there were flow disturbances in all the models evaluated, but the drippers have different behaviors regarding the reduction or increase in flow rate over time of operation. 


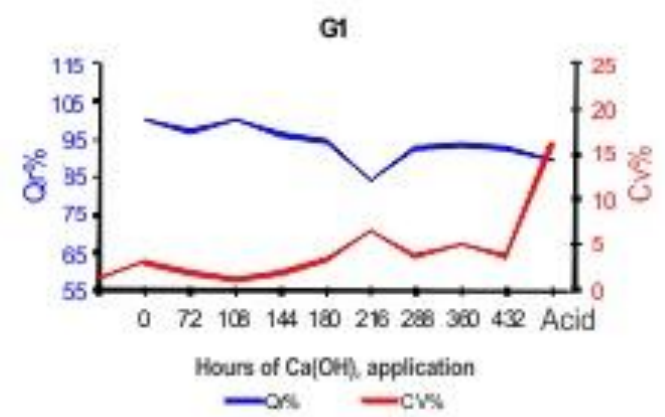

63

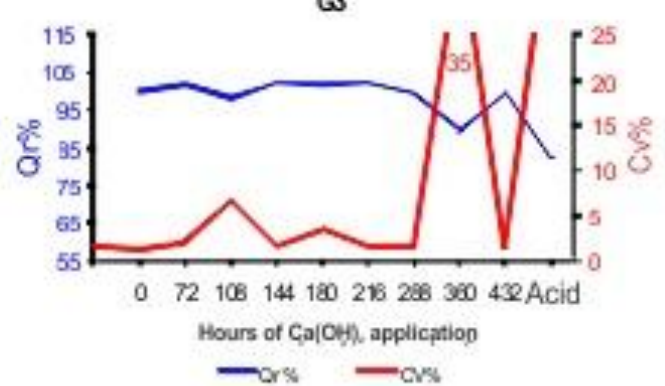

G5

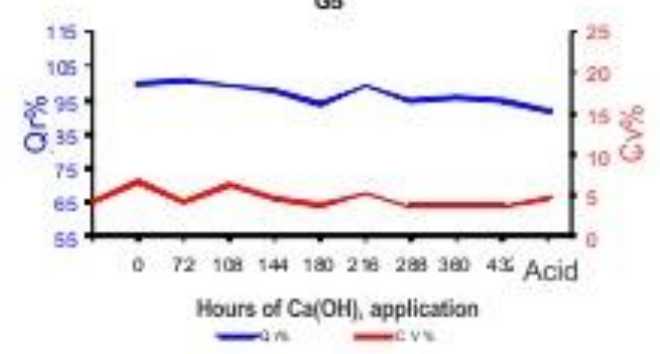

Gr

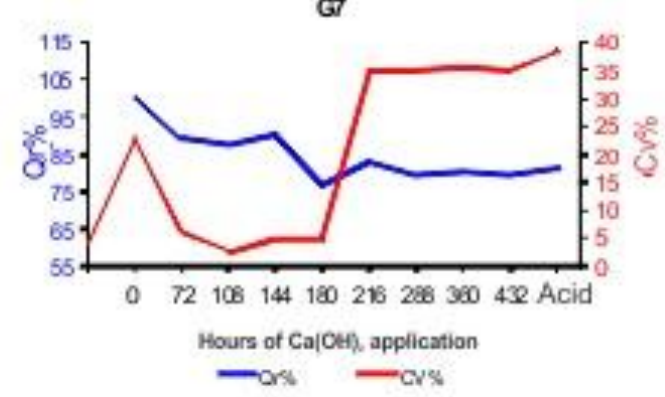

G9

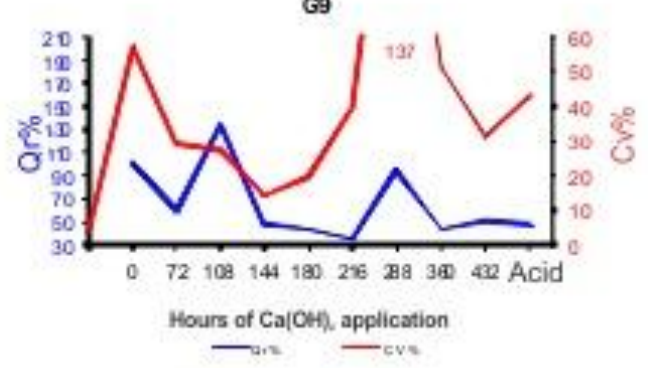

G2

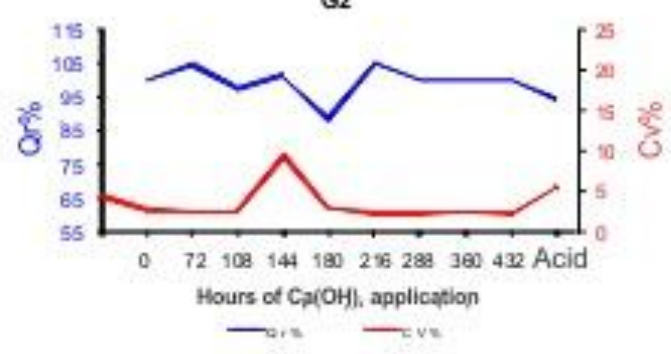

G4

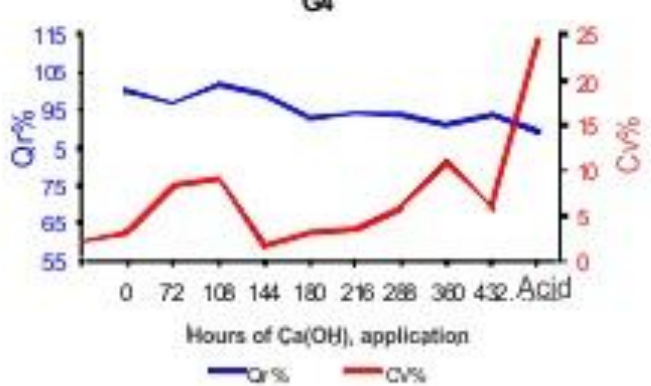

G6

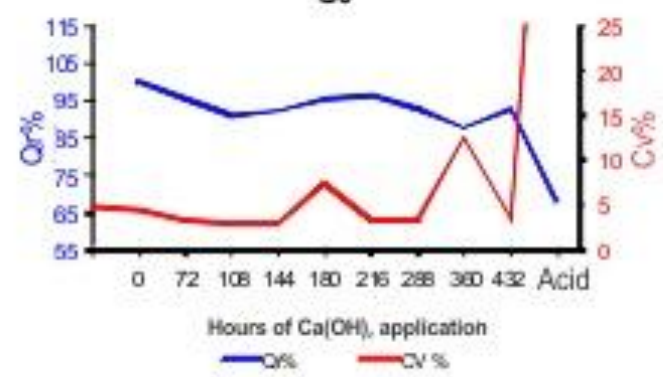

G8

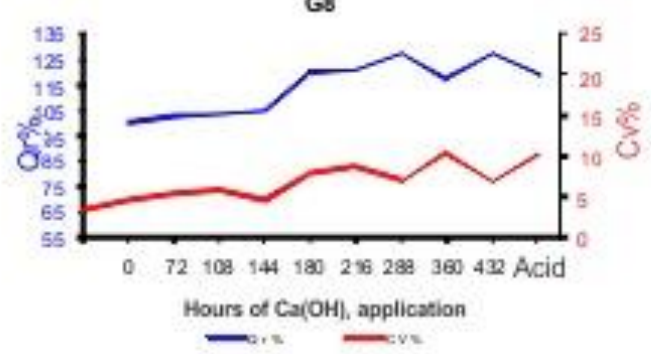

FIGURE 2. Behavior of the flow rate and coefficient of variation throughout the experiment. Mean values of ten emitters.

\section{Susceptibility to blockage}

To analyze the susceptibility to clogging of the emitters, we should always associate the value of $\mathrm{Qr}$ to the value of $\mathrm{CV}$, as these values, when analyzed separately, may lead to misinterpretation. 
Thus, according to the graphs, we might note that the G5 model had low CV values during the experiment. In the G6 model, before applying the acid, the values of $\Delta \mathrm{Qr}$ remained low, $6.17 \%$ ( $\Delta$ Qr $<10 \%$, Barros et al., 2009) and CV values were good, 4.89\% (CV <10\%, HILLEL, 1982). In models G2, G3 and G5, the graphs showed that the Qr values remained with a low range, and CV values are considered good values according to HILLEL (1982). The G7model proved to be susceptible to the application of hydrated lime, presenting values of Qr ranging a lot during the applications, the same occurred for the CV values, reaching a summit top of $38 \%$.

The drip tube G4 presented throughout the experiment decrease of the relative flow according to the growing applications of $\mathrm{Ca}(\mathrm{OH})_{2}$, and also had very inconstant values of $\mathrm{CV}$. As to the $\mathrm{G}$, both the values of Qr and CV have an increasing tendency, which may have caused the abrasion of the drip tube material by solid particles from $\mathrm{Ca}(\mathrm{OH})_{2}$.

For the G9 dripper, these coefficients of variation and relative flow were very inconsistent, and this emitter was one of the most affected by the application of hydrated lime.

Statistical analysis of flow, depending on the application of hydrated lime (Table 2) was made after normalization of the values of Qr, thus allowing comparisons among emitters in the same line and emitters of different models. Statistically, from the nine emitters, eight were not influenced by the application of lime (not significant) throughout the experiment. Only the emitter G9 showed statistically different means in practically all the readings.

The application of acid (reading 10) did not significantly affect the Qr of any of the models evaluated, however, with the observation of $\mathrm{CV}$, one can draw accurate inferences about the clogged of the emitters. The decrease in the flow of the drippers after applying the acid is due to the fact that there was a detachment of larger particles of the tube wall, which were not dissolved by the acid, causing the blockage.

TABLE 2. Statistical analysis of the relative flow rates $\left(\mathrm{L} \mathrm{h}^{-1}\right)$ of the emitters according to the concentration of $\mathrm{Ca}(\mathrm{OH}) 2$ and the application time.

\begin{tabular}{|c|c|c|c|c|c|c|c|c|c|c|}
\hline \multirow[b]{3}{*}{ Models } & \multicolumn{10}{|c|}{ Concentration of $\mathrm{Ca}(\mathrm{OH})_{2}\left(\mathrm{~g} \mathrm{~L}^{-1}\right)$} \\
\hline & 0.00 & 0.01 & 0.02 & 0.92 & 1.41 & 1.41 & 1.84 & 1.84 & 1.84 & \multirow{3}{*}{$\begin{array}{c}\text { After accid } \\
\text { usage }\end{array}$} \\
\hline & $0 \mathrm{~h}$ & $72 \mathrm{~h}$ & $108 \mathrm{~h}$ & $144 \mathrm{~h}$ & $180 \mathrm{~h}$ & $216 \mathrm{~h}$ & $288 \mathrm{~h}$ & $360 \mathrm{~h}$ & $432 \mathrm{~h}$ & \\
\hline \multicolumn{10}{|c|}{ Qr Readings } & \\
\hline G1 & 100Aa & 97.07Aa & $100.18 \mathrm{Aa}$ & $96.36 \mathrm{Aa}$ & 93.98Aa & $83.72 \mathrm{Aa}$ & $92.48 \mathrm{Aa}$ & 93.24Aa & 92.48Aa & $89.4 \mathrm{Aa}$ \\
\hline $\mathrm{G} 2$ & 100Aa & $104.80 \mathrm{Aa}$ & 97.57Aa & $101.33 \mathrm{Aa}$ & $88.28 \mathrm{Aa}$ & 104.9 Aa & $100.1 \mathrm{Aa}$ & $100.3 \mathrm{Aa}$ & 100.1 Aa & $94.5 \mathrm{Aa}$ \\
\hline G3 & $100 \mathrm{Aa}$ & $101.9 \mathrm{Aa}$ & $98.3 \mathrm{Aa}$ & 102.2 Aa & $101.4 \mathrm{Aa}$ & $102.2 \mathrm{Aa}$ & $99.6 \mathrm{Aa}$ & $89.7 \mathrm{Aa}$ & $99.4 \mathrm{Aa}$ & $82.9 \mathrm{Aa}$ \\
\hline G4 & $100 \mathrm{Aa}$ & $97.0 \mathrm{Aa}$ & $101.7 \mathrm{Aa}$ & $99.2 \mathrm{Aa}$ & $92.7 \mathrm{Aa}$ & $94.1 \mathrm{Aa}$ & $94.0 \mathrm{Aa}$ & $90.7 \mathrm{Aa}$ & 94.0Aa & 89.1 Aa \\
\hline G5 & 100Aa & 101.1 Aa & $99.7 \mathrm{Aa}$ & $98.0 \mathrm{Aa}$ & 93.6 Aa & $99.5 \mathrm{Aa}$ & $95.4 \mathrm{Aa}$ & $95.8 \mathrm{Aa}$ & $95.4 \mathrm{Aa}$ & $91.9 \mathrm{Aa}$ \\
\hline G6 & $100 \mathrm{Aa}$ & $95.5 \mathrm{Aa}$ & $91.2 \mathrm{Aa}$ & $92.3 \mathrm{Aa}$ & $96.1 \mathrm{Aa}$ & $96.2 \mathrm{Aa}$ & $92.8 \mathrm{Aa}$ & $87.8 \mathrm{Aa}$ & $92.7 \mathrm{Aa}$ & $68.3 \mathrm{ABa}$ \\
\hline G7 & 100Aa & $88.9 \mathrm{Aa}$ & $87.8 \mathrm{Aa}$ & $90.1 \mathrm{Aa}$ & $76.5 \mathrm{Aa}$ & $83.0 \mathrm{Aa}$ & $79.7 \mathrm{Aa}$ & $80.1 \mathrm{Aa}$ & $79.7 \mathrm{ABa}$ & $81.0 \mathrm{Aa}$ \\
\hline G8 & $100 \mathrm{Aa}$ & 103.0 Aa & $103.6 \mathrm{Aa}$ & 105.0 Aa & $120.6 \mathrm{Aa}$ & $120.8 \mathrm{Aa}$ & $127.9 \mathrm{Aa}$ & $118.0 \mathrm{Aa}$ & $127.9 \mathrm{Aa}$ & $119.2 \mathrm{Aa}$ \\
\hline G9 & $100 \mathrm{Aab}$ & $59.0 \mathrm{Abc}$ & $133.2 \mathrm{Aa}$ & 47.7 Bde & 44.2 Bde & $35.4 \mathrm{Be}$ & 94.9 Aab & 43.4 Bde & $50.6 \mathrm{Bcd}$ & 47.6 Bde \\
\hline
\end{tabular}

Means followed by same capital letter in the column do not differ at the 0.05 level of probability. Means followed by same letter in the line do not differ at the 0.05 level of probability.

\section{Effect of acid}

It is noticed that the application of the acid had a negative effect in six treatments $(\mathrm{G} 1, \mathrm{G} 2$, G3, G4, G6, G8 and G9), affecting the CV through the clogging of some emitters in individual lines, this is due to the fact that, after applying the acid, there was a detachment of larger particles of the tube wall, which were not dissolved by the acid, causing the clogging. Only emitter G5 and G7 showed no sensitivity to acid, maintaining the values of CV and Qr virtually unchanged. 
From the data, a classification of models was made according to the proposal of BARROS et al. (2009) to compare the sensitivity of the emitters to the application of $\mathrm{Ca}(\mathrm{OH})_{2}$.

We compared the means of $\mathrm{CV}$ during the experiment and relative flow rate in relation to the beginning of the experiment, and classified according to BARROS et al. (2009) as:

- Non-sensitive $(\Delta \mathrm{Qr}<10 \%$ and $\mathrm{CV}<5.5 \%)$ emitters G2 and G5;

- Sensitive ( $\Delta$ Qr $<20 \%$ and CV $<15 \%)$ emitters G1, G3, G4 and G8, and as

- Very sensitive $(\Delta \mathrm{Qr}>20 \%$ and CV> 15\%) emitters G6, G7 and G9.

The results are different from the ones commented in the statistical analysis, in which none of the models showed high sensitivity to clogging by lime. From the statistical analysis, only the G9 model was sensitive to hydrated lime. This is due to the fact that the statistical analysis used in this approach was based on the collected flow, excluding the coefficient of variation that occurs in reading, since the emitters are not likely to increase or decrease the flow at the same time interval. Ergo, the CV and Qr are most appropriate parameters to conclude whether the models are sensitive to clogging or not. BARROS et al. (2009), when evaluating clogging of drippers, used the values of $\mathrm{CV}$ and $\mathrm{Qr}$ in the classification and conclusion about the emitters, which corroborates with the parameters used.

\section{Total Clogging}

According to what was observed during the experiment, it is clear that there is no relation between drip tubes with smaller values of nominal flow rate and clogging, although their output diameters are smaller. Then, what can be inferred is that there is a relation with the geometry of the emitter and the maze distance covered by the water.

The total clogging of drippers can be easily detected in the field, but it is more harmful when compared to partial clogging, because it causes a high non-uniformity of water distribution to the plants.

\section{CONCLUSIONS}

The mean flow rate of the non compensate drip tubes remained statistically unchanged after applying the acid in all models, except the G9.

Considering the classification according to $\mathrm{CV}$ and Qr, the best results were obtained in the drip tubes G2 and G5, slightly decreasing in their Qr values associated with flow coefficients of variation always below $10 \%$, considered good.

There was no relation between drip tubes with smaller values of nominal flow rate and clogging, although their output diameters were smaller.

\section{REFERENCES}

ALCARDE, J.C. Corretivos de acidez dos solos: características e interpretações técnicas. São Paulo: ANDA - Associação Nacional Para Difusão de Adubos e Corretivos Agrícolas, 1992. (Boletim Técnico, 6)

BARROS, A.C.; COELHO, R.D. ; MEDEIROS, P.R.F. ; MELO, R.F.; BARBOZA JÚNIOR, C.R.A. ; DIAS, C.T.S. Entupimento de gotejadores em função da aplicação de superfosfato simples e ácido nítrico. Engenharia Agrícola, Jaboticabal, v.29, n.1, p.62-71, 2009.

BERNARDO, S.; SOARES, A.A.; MANTOVANI, E.C. Manual de irrigação. 8.ed. Viçosa: UFV, 2006. $625 \mathrm{p}$.

DIAS, N.S.; OLIVEIRA, M.V.A.M.; COELHO, R.D. Resistência de diferentes tipos de tubogotejadores ao entupimento por precipitação química de cálcio. Irriga, Botucatu, v.9, n.2, p.115-125, 2004. 
HILLEL, D. Advances in irrigation. New York: Academic Press, 1992. v.1. 302 p.

MEYER, J.L. Cleaning drip irrigation systems. In: INTERNATIONAL DRIP/TRICKLE

IRRIGATION CONGRESS, 3., 1985, Fresno. Proceedings... Saint Joseph: ASAE, 1985. v.1,p. 4144.

PIZARRO, F. Riegos localizados de alta frequencia. 3.ed. MadriD: Mundi Prensa, 1996. 513 p.

RESENDE, R.S. Suscetibilidade de gotejadores ao entupimento de causa biológica e avaliação do desentupimento via cloração da água de irrigação. 1999. 77 f. Dissertação (Mestrado em Irrigação e drenagem) - Escola Superior de Agricultura "Luiz de Queiroz", Universidade de São Paulo, Piracicaba, 1999.

SAS INSTITUTE. Statistical analysis system. SAS/STAT software. SAS user's guide: Statistics, ver. 8.2. Cary, 2003.

SOLOMON, K. Manufacturing variation of trickle irrigation systems. Transactions of the ASAE, St. Joseph, v.22, n.5, p.1034-1038; 1043, 1979.

TEIXEIRA, M.B. Efeitos de dosagens extremas de cloro e pH na vazão de gotejadores autocompensantes (Irrigação localizada). 2006. 322 f. Tese (Doutorado em Irrigação e Drenagem) - Escola Superior de Agricultura “Luiz de Queiroz”, Universidade de São Paulo, Piracicaba, 2006. 